NOTE

\title{
Pollen limitation in a dioecious seagrass: evidence from a field experiment
}

\author{
Brigitta I. van Tussenbroek ${ }^{1, *}$, Manuela Muhlia Montero ${ }^{1}$, Ricardo Wong $^{2}$, \\ M. Guadalupe Barba Santos ${ }^{1}$, Judith Márquez Guzmán ${ }^{2}$ \\ ${ }^{1}$ Unidad Académica Sistemas Arrecifales/ Puerto Morelos, Instituto de Ciencias del Mar y Limnología, Universidad Nacional \\ Autónoma de México, Apdo. Postal 1152, Cancún, 77500 Quintana Roo, Mexico \\ ${ }^{2}$ Facultad de Ciencias, Universidad Nacional Autónoma de México, Laboratorio del Desarrollo en Plantas, Circuito Exterior, \\ Ciudad Universitaria, Del. Coyoacán, México, DF 04510, Mexico
}

\begin{abstract}
Pollen limitation is relatively common in plants pollinated by animals, but whether pollen availability may limit the reproduction of water-pollinated plants is much less known. We investigated pollen production and possible limitation of pollen availability in the hydrophilous dioecious seagrass Thalassia testudinum in an area where flowering was abundant (20 to $33 \%$ of the shoots produced flowers annually). Fruit production decreased from 86 to $60 \%$ after experimental removal of half of the male flowers (estimated pollen:ovule ratio of $6.7 \times 10^{4}: 1$ ) during April 2008. In late April to May 2009, when male flowers were less abundant than in the previous year (at a pollen:ovule ratio of $3.7 \times 10^{4}: 1$ ), artificial pollination resulted in an increase in fruit production from $65 \%$ in control flowers to $91 \%$ in the treated flowers in the same plot. This study is the first experimental evidence of pollen limitation in a dioecious plant with hydrophilous pollination.
\end{abstract}

KEY WORDS: Fruit-set $\cdot$ Hydrophilous pollination $\cdot$ Seagrass $\cdot$ Seed-set $\cdot$ Thalassia

Resale or republication not permitted without written consent of the publisher

\section{INTRODUCTION}

Approximately $20 \%$ of all flowering plants depend on air or water to transport their pollen (Ackerman 2000). Plants displaying abiotic pollination typically produce copious amounts of pollen (Ackerman 2000, 2006, Cruden 2000). However, a high pollen production does not necessarily imply that pollen loads are sufficient to fertilize all available ovules. Pollen limitation, that is, limitation of female reproductive success due to inadequate pollen receipt, is not uncommon in animal-pollinated plants (Burd 1994, Ashman et al. 2004, Harder \& Aizen 2010), but such information on plants pollinated abiotically is sparse. Various studies suggest that wind-pollinated trees in fragmented habitats or widely spaced populations may suffer from pollen limitation (Allison 1990, Fox 1992, Knapp et al. 2001, Sork et al. 2002, Koenig \& Ashley 2003). Low density also affects seed-set in wind-pollinated herbs (Davis et al. 2004a,b, Steven \& Waller 2007), but Fried- man \& Barrett (2009) mention that pollen limitation may be less common among terrestrial anemophilous herbaceous plants than in animal-pollinated species.

Seagrasses are an ecological group of marine flowering plants with pollen transport at or below the water surface (hydrophily). In a pattern similar to that of the abiotic wind-pollinated plants (Okubo \& Levin 1989, Davis et al. 2004a, Friedman \& Barrett 2009), seagrasses show leptokurtic pollen dispersal curves, mediated by current direction, turbulence and buoyancy of the pollen combined with characteristics of the plant and vegetation such as canopy height, canopy density, plant height and floral position within the canopy (see Ackerman 2006 for summary). Absolute distances covered by hydrophilous pollen are much shorter than those for pollen dispersed by wind $\left(10^{2}\right.$ to $10^{3} \mathrm{~m}$, Okubo \& Levin 1989, but see Koenig \& Ashley 2003), and they are usually in the order of metres (Cox \& Tomlinson 1988, Ruckelshaus 1996, Verduin \& Backhaus 2000, Ackerman 2002, Smith \& Walker 2002, 
Sanabria-Alcaraz 2009). Hydrophilous seagrasses with subaquatic pollination have pollen:ovule ratios of $10^{4}$ to $10^{5}: 1$ (Ackerman 2006); $>90 \%$ of the species have unisexual flowers (Les et al. 1997), and $\sim 75 \%$ of the species are dioecious (Cox 1988). Such plants rely on the transport of pollen between flowers for sexual reproduction, and, in the case of dioecy, the relative distribution of male and female plants in a population may limit reproductive success. For example, male rarity has been reported for Phyllospadix spp., which grow on rocky shores (Williams 1995, Shelton 2008). Shelton (2008) reported that populations with increased male rarity in 2 Phyllospadix species had lower rates of seed-set. Phyllospadix spp. may be considered an extreme case among the seagrasses, but some seagrasses that show less-skewed sex ratios have also shown indications of pollen limitation. Reusch (2003) found reduced seed-set after experimental reduction in flowering shoots of the monoecious Zostera marina, this being the only recorded experimental evidence of pollen limitation in a hydrophilous plant. Vermaat et al. (2004) reported decreased fruit development in fragmented habitats of the dioecious surface-pollinated Enhalus acoroides.

Inadequate pollination results in reduced production of fruits and seeds, which affects plant abundance and population viability and may thus cause selection on plant mating systems and floral traits (Ashman et al. 2004, Knight et al. 2005). In theory, any plant should be in a pollen resource equilibrium, and if the availability of pollen would limit reproductive success, it is expected to have evolved mechanisms of reproductive assurance, reducing the potential for pollen limitation in the future (Ashman et al. 2004, Knight et al. 2005). But ecological disturbances, such as habitat fragmentation, decreased floral density, herbivore pressure, diseases and invasion of nonnative species (Knight et al. 2005, their Table 1) may reduce the probability of fecundation, thus generating lower recruitment rates and potentially affecting population persistence and expansion rates. For the highly clonal seagrasses, effects of reduced reproductive output are expected to be less obvious at a demographic level, but genetic consequences over larger ecological time spans or evolutionary processes may be considerable (Waycott et al. 2006).

In the present study, we examined whether the dioecious tropical seagrass Thalassia testudinum might suffer from reduced reproductive output due to insufficient pollen receipt under suboptimal conditions. We selected a population with abundant flowers and male dominance and we hypothesized that this specific population was in a state of pollen resource equilibrium under natural conditions. To evaluate whether pollen limitation could occur, we experimentally manipulated densities of male flowers and forced pollination of female flowers in situ and determined the consequences on reproductive success.

\section{MATERIALS AND METHODS}

We studied in situ the effect of experimental pollen reduction (elimination of male flowers) or addition (artificial pollination) on the fruit and seed-set of Thalassia testudinum at Puerto Morelos reef lagoon $\left(20^{\circ} 51^{\prime} 854^{\prime \prime} \mathrm{N}, 86^{\circ} 51^{\prime} 492^{\prime \prime} \mathrm{W}\right)$ at $\sim 100$ to $200 \mathrm{~m}$ from a fringing reef and at $\sim 3.5 \mathrm{~m}$ depth. The site is relatively exposed to wave action and maximal current velocities at the height of the seagrass canopy vary between 5 and $25 \mathrm{~cm} \mathrm{~s}^{-1}$ on relatively calm days during the flowering season (Sanabria-Alcaraz 2009). Further information on the study site can be found in RodríguezMartínez et al. (2010). The seagrass bed is dominated by $T$. testudinum (with, on average, $700 \pm 170$ [SD] shoots $\mathrm{m}^{-2}$ in 2008 and $689 \pm 154$ shoots $\mathrm{m}^{-2}$ in 2009) and were accompanied by the seagrass Syringodium filiforme and sparse rhizophytic algae (RodríguezMartínez et al. 2010). Here, flowers of T. testudinum are relatively abundant (between 20 and $33 \%$ of the shoots produced flowers each year) and the male and female clones grow intermixed (Van Tussenbroek 1994, B. I. van Tussenbroek unpubl. data). Floral buds are situated in the axils of the leaves below the sediment until anthesis, and flowers emerge above the sediment for only a short time ( $6 \mathrm{~h}$ for the male flowers, Van Tussenbroek et al. 2008). The male flowers occur in groups of 2 or 3 that dehisce sequentially, and female flowers are usually solitary. Pollen grains are released in strands or masses of neutrally to slightly negatively buoyant mucilage (Cox \& Tomlinson 1988, Van Tussenbroek et al. 2009). Pollen does not travel far in this area, with only $\sim 3$ to $8 \%$ of the pollen dispersing $\geq 3 \mathrm{~m}$ from the source, although a few grains may be transported over distances of $\geq 8 \mathrm{~m}$ depending on the hydrodynamic conditions (Sanabria-Alcaraz 2009).

In April of 2008 and 2009, the number of fresh flowers or flower buds at pre-anthesis (stretched bud phase reported in Van Tussenbroek et al. 2008) was determined in 10 haphazardly placed quadrats of $2 \times 2 \mathrm{~m}$ in an area of $\sim 50 \times 150 \mathrm{~m}$ parallel to the reef. In both years, 30 mature male buds were collected randomly in the area to determine the number of anthers and to measure with a dial caliper (precision, $0.1 \mathrm{~mm}$ ) the lengths of the anther-bearing parts. Pollen counts were performed on 3 mature fresh buds of average size collected in 2008, and 24 buds collected in 2009. The anthers were placed in a $15 \mathrm{ml} 0.01 \%$ solution of Nonidet $\mathrm{P}_{40}$ substitute detergent in filtered seawater and agitated at regular intervals to separate the pollen 
grains from the mucilage. After 1 to $2 \mathrm{~d}$, pollen grains in 10 subsamples were counted with the aid of a haemacytometer (volume, $0.9 \mu \mathrm{l}$ ). The number of ovules was determined on 30 and 50 randomly collected fruits at the end of the experimental period of 2008 and 2009, respectively.

In April 2008, a circular area with a radius of $6 \mathrm{~m}$ was defined by a cord fixed to a haphazardly selected central point. Within this area, all shoots bearing male flowers and buds were located by removal of the sediment, and alternate shoots were marked with a distinctly coloured tag followed by removal of all flowers and buds on shoots marked with the same colour; hence, $\sim 50 \%$ of male flowers were removed. Within the $6 \mathrm{~m}$ circular area a $4 \times 4 \mathrm{~m}$ experimental plot was defined. This created a buffer zone of almost $4 \mathrm{~m}$ around the central experimental plot, which minimized the potential for fertilization from pollen outside the plot. In the central experimental plot, the female buds were located and marked with a small bar with an attached tag. This procedure was repeated, resulting in 2 replicas of the removal $(\mathrm{R})$ treatment. We returned on 2 subsequent occasions within 2 wk after the removal of male flowers to tag newly emerged female flowers in the 2 central experimental plots with 59 and 43 female flowers, respectively. The 2 control plots (CR: control, no removal) received no treatment at all and consisted of, respectively, 46 and 51 marked female buds in plots of the same dimensions. The setup took approximately $2 \mathrm{wk}$ and was finished by the end of April. Meteorological and hydrodynamic conditions were calm during this period, with wind velocities of $\leq 1 \mathrm{~m} \mathrm{~s}^{-1}$ and surface currents of 1.5 to $4.0 \mathrm{~cm} \mathrm{~s}^{-1}$ (data from Servicio Académico de Hidrología y Meteorología, Unidad Académica Sistemas Arrecifales/ Puerto Morelos [SAHM, UASA/PM], Instituto de Ciencias del Mar y Limnología [ICML], Universidad Nacional Autónoma de México [UNAM]). After 1 mo, at the end of May, developed fruits and aborted ovaries were counted. Developed fruits were firm and green, whereas aborted ovaries were brown without any visible development and showed signs of disintegration. Fresh green fruits with bite marks were considered as developed fruits. On occasions, tags were lost, which reduced the number of samples. The fruits were left to mature and harvested in late July, but many were consumed by herbivorous fish. In the laboratory the fruits were opened and the numbers of viable large seeds with plumule (Thalassia testudinum is pseudoviviparous, Van Tussenbroek et al. 2006) and aborted ovules, which had remained small, were determined per fruit.

In 2009, pollen was added to female flowers in 2 newly established plots of $\sim 3 \times 12 \mathrm{~m}$ in the same study site as in 2008 (Treatment P: pollen addition). Early in the morning in mid-April, 40 female flower buds that had stretched and were expected to open in the course of the day were marked in the first plot. In the evening of the same day, 5 to 7 male flowers in anthesis were harvested and we gently rubbed the stigmas of the previously marked and recently opened female flowers with the male flowers. The same set of male flowers was used for $\sim 10$ female flowers; previous trials in the laboratory showed that this procedure resulted in ample pollen supply to the stigmas. The stigmas were receptive immediately after opening of the female flowers (Van Tussenbroek et al. 2009), and they were pollinated in the evening because the male flowers dehisce at dusk (Van Tussenbroek et al. 2008) and pollen grains were short-lived (only 50 to $60 \%$ of the pollen grains were viable after $13 \mathrm{~h}$, Van Tussenbroek et al. 2009). The following day, 40 additional recently opened female flowers were marked as controls (CP: control, no pollen addition) in the same plot. Two weeks later, at the beginning of May, this procedure was repeated for a second experimental plot. Meteorological conditions were also calm during the latter days with wind velocities of $\leq 1 \mathrm{~m} \mathrm{~s}^{-1}$ (data from SAHM, UASA/PM, ICML, UNAM). Monitoring of fruits and seeds followed the procedures of 2008. The fruits were protected from herbivores by covering them with a small plastic mesh; however, during 2009, the fruit matured earlier than in previous years (possibly because water temperatures were higher than usual) and many had dehisced before collection.

Differences in the proportion of developed fruits (of marked flowers) and seeds (of ovules in ovaries) were tested by 1 -way ANOVA (at $\alpha=0.10$, to reduce the possibility of a Type I error), with the treatments (R, CR, P, CP) as fixed factors. A post-hoc Tukey's Honestly Significant Difference (HSD) test was applied to determine which treatments differed significantly from each other. Data were arcsine transformed to approach normality.

\section{RESULTS}

During the experimental period in April 2008, the mean density of fresh male flowers or flower buds at pre-anthesis varied between 3 and 26 per $4 \mathrm{~m}^{2}$ (mean $\pm \mathrm{SD}: 15.0 \pm 6.90, \mathrm{~N}=10$ ), and there were 1 to 24 $(10.2 \pm 6.3, \mathrm{~N}=10)$ fresh female flowers (or buds at preanthesis) per $4 \mathrm{~m}^{2}$. In April to May 2009, we found 2 to $15(8.2 \pm 3.8, \mathrm{~N}=10)$ male and 1 to $21(11.7 \pm 6.9, \mathrm{~N}=10)$ female flowers per $4 \mathrm{~m}^{2}$. The mature male buds varied little in size in the study area; in 2008 they were, on average, $9.90 \pm 5.85 \mathrm{~mm}$ long $(\mathrm{N}=30)$ with $9.1 \pm 0.50$ anthers and in 2009 they were, on average, $9.84 \pm$ $0.58 \mathrm{~mm}$ long with $9.0 \pm 0.55$ anthers $(\mathrm{N}=30)$. A male flower yielded, on average, $1.56 \times 10^{5} \pm 2.93 \times 10^{4}$ pollen grains $(\mathrm{N}=3)$ in 2008 and $1.60 \times 10^{5} \pm 3.52 \times 10^{4}$ 
$(\mathrm{N}=24)$ in 2009. The ovary of a female flower contained 2 to 6 ovules, with an average of $3.4 \pm 0.97$ ovules $(\mathrm{N}=$ $50)$ in 2008 and $3.0 \pm 1.12$ ovules $(\mathrm{N}=50)$ in 2009. At the time of the experiments, the proportions of male to female flowers were 1.47:1 and 0.70:1 in 2008 and 2009, respectively, resulting in a pollen:ovule ratio of $6.7 \times$ $10^{4}: 1$ in the first year and $3.7 \times 10^{4}: 1$ in the second.

After $50 \%$ reduction of the male flowers in 2008, we observed reduced fruit-set and seed development, and artificial pollen addition to the female flowers in 2009 resulted in increased fruit- and seed-set when compared with the untreated flowers (Fig. 1). When the data of 2008 and 2009 were combined and tested by 1-way ANOVA, the proportion of developed fruits of all marked fruits (fruit-set) varied significantly between the treatments $(F=26.63, \mathrm{df}=3, \mathrm{p}=0.004)$. The post-hoc Tukey's HSD test revealed 2 subsets: (1) R (removal of males in 2008) and CP (control, no pollination in 2009) and (2) CR (control, no removal of males in 2008) and $P$ (pollen addition in 2009). The seed-set (proportion of developed seeds of all ovules in the ovaries) also varied significantly between abovementioned treatments $(F=5.032$, df $=3, \mathrm{p}=0.076)$, but the post-hoc test did not reveal subsets.
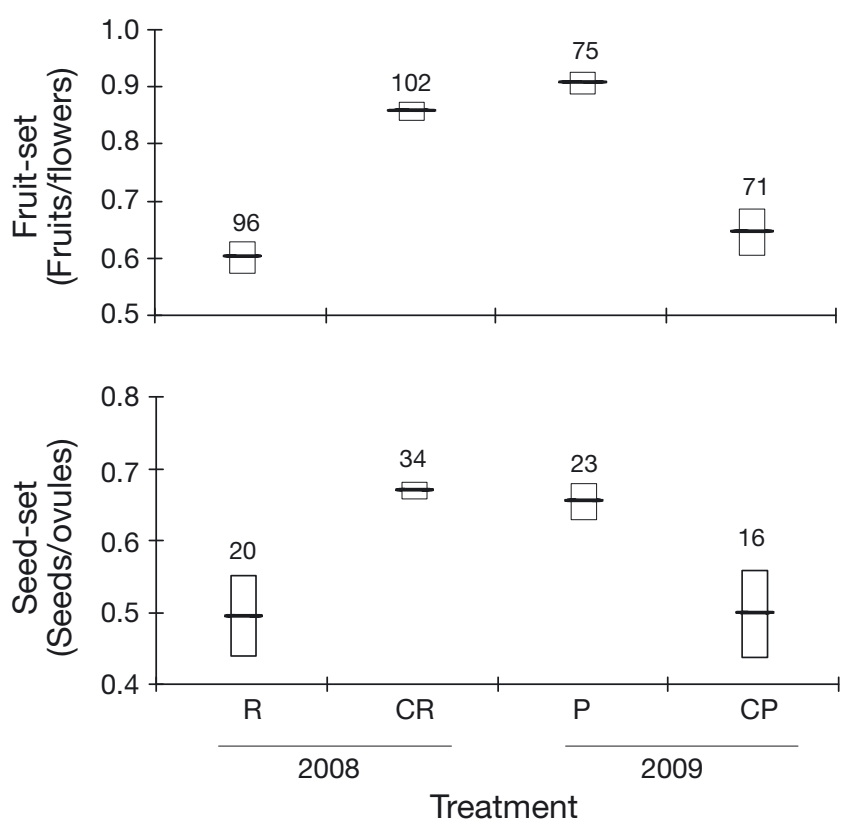

Fig. 1. Thalassia testudinum. Fruit-set and seed-set for the different treatments applied to the dioecious seagrass in Puerto Morelos reef lagoon, indicating mean \pm range (rectangle). Fruit-set was determined at the beginning of June, whereas seed-set was evaluated for mature remaining fruits at the end of July when many marked fruits were lost due to herbivore pressure (2008) or dehiscence before collection (2009). Numbers indicate sample size. R: removal of males; CR: control, no removal of males; P: pollen addition; CP: control, no pollen addition

\section{DISCUSSION}

Our results show that when $50 \%$ of the male flowers were eliminated in 2008, Thalassia testudinum suffered a reduction of $25 \%$ and $18 \%$ in fruit- and seed-set, respectively. In the 2009 experiment, when natural male abundance was low, the increased fruit-set (26\%) and seed-set $(15 \%)$ after the artificial addition of pollen, indicated that during this year, the untreated female flowers (controls) were pollen-limited. Thus, when fewer male flowers were present, fewer female flowers were fertilized and those that were fertilized produced fewer seeds; the latter effect was unexpected because pollen of $T$. testudinum is released in mucilage, which would imply pollen capture in packages. However, Sanabria-Alcaraz (2009) found both single and multiple grains in pollen traps, so pollen grains may also be transported independently.

As far as we know, this is the first report of experimental evidence of pollen limitation in a dioecious plant with hydrophilous pollination. Ackerman (2002) simulated pollen capture of the monoecious Zostera marina related to hydrodynamic regimes within the canopy and found that this seagrass required $10^{3}$ to $10^{4}$ pollen grains to pollinate a single flower, which corresponds with the pollen to ovule ratio of $10^{4}: 1$ for this seagrass (Ackerman 1993). Because pollen transport is limited in seagrasses, pollination success within a population may be strongly related to the density and distribution of flowers within that population. Reusch (2003) experimentally removed and added flowering shoots of Zostera marina (with male and female flowers within a single inflorescence) and found that seed-set was positively related to floral density until saturation was reached. In 2009, the density of the male flowers of Thalassia testudinum was lower ( 2 flowers or mature buds $\mathrm{m}^{-2}$ ) than in 2008 (almost 4 flowers or mature buds $\mathrm{m}^{-2}$ ) or in other years (Van Tussenbroek 1994, B. I. van Tussenbroek unpubl. data). In 2009, forced pollination resulted in a fruit-set $(91 \%)$ comparable with that of the control treatment in 2008 (86\%). Thus, in 2008 , the system was probably near pollen-resource equilibrium, whereas in 2009, when male frequency was lower (and female presence only slightly higher), pollen was limited. Flowering densities in the study area are in the upper range reported for T. testudinum in comparison with most other areas in the Puerto Morelos reef lagoon (Van Tussenbroek 1994, B. I. van Tussenbroek unpubl. data), the Mexican tropical Atlantic coast (Van Dijk \& Van Tussenbroek 2010) and other geographical areas (Van Tussenbroek et al. 2006). Thus, T. testudinum may be pollen limited under many circumstances. The present study on T. testudinum and those on Zostera marina (Reusch 2003), Enhalus acoroides (Vermaat et al. 2004) and 
Phyllospadix spp. (Shelton 2008) may be examples of a more general rule that hydrophilous plants suffer from insufficient pollen supply under suboptimal environmental conditions.

Wind pollination is thought to have evolved after insect pollination as a mechanism of reproductive assurance in the absence of animal pollinators (Culley et al. 2002, Friedman \& Barrett 2009). Many anemophilous angiosperms are also pollinated by insects (Fox 1992, Culley et al. 2002), and Friedman \& Barrett (2009) found that only 1 of the 10 studied wind-pollinated herbs showed increased seed-set after artificial pollination. Seagrasses, on the other hand, are obligate abiotically pollinated plants. When the seagrasses invaded the sea, they most probably suffered from dilution of the pollen in the turbulent aquatic environment, similar to the gamete dilution of sedentary marine free-spawning animals and seaweeds (Levitan \& Petersen 1995, Yund 2000). Morphological features such as highly reduced floral structures, filamentous pollen, elongated stigmas or the prevalence of dicliny are considered to be adaptations to the transport and interception of pollen in the aquatic medium (see Ackerman 2006 for summary). However, there are other traits of the hydrophilous syndrome that are better explained as a response to pollen dilution, such as copious pollen production and mechanisms of pollen concentration, for example pollen release in mucilaginous masses or strands (Ackerman 2006), restricted flowering periods (Inglis \& Lincoln Smith 1998, Walker et al. 2001, Van Tussenbroek et al. 2009) or synchronized pollen release (Van Tussenbroek et al. 2008, 2009). Thus, pollen limitation could have been an important selective agent in the evolution of the life history characteristics for this ecological group of marine angiosperms.

Acknowledgements. The present work was part of the Masters project of M.M.M. funded by Instituto de Ciencias del Mar y Limnología, Universidad Nacional Autónoma de México (UNAM), and the projects IN213307 (PAPPIIT, UNAM) and 82652 (CB2007-1, CONACyT). The help of T. Valdivia Carrillo and L. F. González Morales is greatly appreciated.

\section{LITERATURE CITED}

Ackerman JD (1993) Pollen germination and pollen tube growth in the marine angiosperm, Zostera marina L. Aquat Bot 46:189-202

Ackerman JD (2000) Abiotic pollen and pollination: ecological, functional and evolutionary perspectives. Plant Syst Evol 222:167-185

Ackerman JD (2002) Diffusivity in a marine macrophyte canopy: implications for submarine pollination and dispersal. Am J Bot 89:1119-1127

Ackerman JD (2006) Sexual reproduction of seagrasses: pollination in the marine context. In: Larkum, AWD, Orth RJ, Duarte CM (eds) Seagrasses: biology, ecology and conservation. Springer, Dordrecht, p 89-109
Allison TD (1990) Pollen production and plant density affect pollination and seed production in Taxus canadensis. Ecology 71:516-522

Ashman TL, Knight TM, Steets JA, Amarasekare P and others (2004) Pollen limitation of plant reproduction: ecological and evolutionary causes and consequences. Ecology 85: 2408-2421

Burd M (1994) Bateman's principle and plant reproduction: the role of pollen limitation in fruit and seed set. Bot Rev 60:83-139

> Cox PA (1988) Hydrophilous pollination. Annu Rev Ecol Syst 19:261-280

Cox PA, Tomlinson PB (1988) Pollination ecology of seagrass, Thalassia testudinum (Hydrocharitaceae), in St. Croix. Am J Bot 75:958-965

Cruden RW (2000) Pollen grains: why so many? Plant Syst Evol 222:143-165

Culley TM, Weller SG, Sakai AK (2002) The evolution of wind pollination in angiosperms. Trends Ecol Evol 17: 361-369

Davis HG, Taylor CM, Civille JC, Strong DR (2004a) An Allee effect at the front of a plant invasion: Spartina in a Pacific estuary. J Ecol 92:321-327

Davis HG, Taylor CM, Lambrinos JG, Strong DR (2004b) Pollen limitation causes an Allee effect in a wind-pollinated invasive grass (Spartina alterniflora). Proc Natl Acad Sci USA 101:13804-13807

Fox JF (1992) Pollen limitation of reproductive effort in willows. Oecologia 90:283-287

> Friedman J, Barrett SCH (2009) Wind of change: new insights on the ecology and evolution of pollination and mating in wind-pollinated plants. Ann Bot 103:1515-1527

Harder LD, Aizen MA (2010) Floral adaptation and diversification under pollen limitation. Philos Trans R Soc Lond B Biol Sci 365:529-543

Inglis GJ, Lincoln Smith MP (1998) Synchronous flowering of estuarine seagrass meadows. Aquat Bot 60:37-48

> Knapp EE, Goedde MA, Rice KJ (2001) Pollen-limited reproduction in blue oak: implications for wind pollination in fragmented populations. Oecologia 128:48-55

> Knight TM, Steets JA, Vamosi JC, Mazer SJ and others (2005) Pollen limitation of plant reproduction: patterns and processes. Annu Rev Ecol Evol Syst 36:467-497

Koenig WD, Ashley MV (2003) Is pollen limited? The answer is blowin' in the wind. Trends Ecol Evol 18:157-159

Les DH, Cleland MA, Waycott M (1997) Phylogenetic studies in Alismatidae, II. Evolution of marine angiosperms (seagrasses) and hydrophily. Syst Bot 22:443-463

Levitan DR, Petersen C (1995) Sperm limitation in the sea. Trends Ecol Evol 10:228-231

- Okubo A, Levin SA (1989) A theoretical framework for data analysis of wind dispersal of seeds and pollen. Ecology 70 : 329-338

> Reusch TBH (2003) Floral neighbourhoods in the sea: how floral density, opportunity for outcrossing and population fragmentation affect seed set in Zostera marina. J Ecol 91: 610-615

Rodríguez-Martínez RE, Ruíz-Rentería F, Van Tussenbroek B, Barba-Santos G, Escalante-Mancera E, Jordán-Garza G, Jordán-Dahlgren E (2010) Environmental state and tendencies of the Puerto Morelos CARICOMP site, Mexico. Rev Biol Trop 58:23-43

$>$ Ruckelshaus MH (1996) Estimation of genetic neighbourhood parameters from pollen and seed dispersal in the marine angiosperm Zostera marina L. Evolution 50:856-864

Sanabria-Alcaraz SNM (2009) Rango de dispersión del polen de Thalassia testudinum en la laguna arrecifal de Puerto 
Morelos. Honors dissertation, Universidad Nacional Autónoma de México

Shelton AO (2008) Skewed sex ratios, pollen limitation, and reproductive failure in the dioecious seagrass Phyllospadix. Ecology 89:3020-3029

Smith NM, Walker DI (2002) Canopy structure and pollination biology of the seagrass Posidonia australis and P. sinuosa (Posidoneaceae). Aquat Bot 74:57-70

Sork VL, Davis FW, Smouse PE, Apsit J, Dyer RJ, Fernandez M JF, Kuhn B (2002) Pollen movement in declining populations of California Valley oak, Quercus lobata: Where have all the fathers gone? Mol Ecol 11: 1657-1668

Steven JC, Waller DM (2007) Isolation affects reproductive success in low-density but not high-density populations of two wind-pollinated Thalictrum species. Plant Ecol 190: 131-141

> Van Dijk JK, Van Tussenbroek BI (2010) Clonal diversity and structure related to habitat of the marine angiosperm Thalassia testudinum along the Atlantic coast of Mexico. Aquat Bot 92:63-69

Van Tussenbroek BI (1994) Aspects of the reproductive ecology of Thalassia testudium in Puerto Morelos reef lagoon, Mexico. Bot Mar 37:413-419

Van Tussenbroek BI, Vonk JA, Stapel J, Erftemeijer PLA, Middelburg JJ, Zieman JC (2006) The biology of Thalassia. Paradigms and recent advances in research. In: Larkum AWD, Orth, RJ, Duarte CM (eds) Seagrasses: biology, ecology and conservation. Springer, Dordrecht, p 409-439

Editorial responsibility: Kenneth Heck Jr., Dauphin Island, Alabama, USA
Van Tussenbroek BI, Marquéz-Guzmán J, Wong R (2008) Synchronized anthesis and predation on pollen in the marine angiosperm Thalassia testudinum (Hydrocharitaceae). Mar Ecol Prog Ser 354:119-124

Van Tussenbroek BI, Marquéz-Guzmán J, Wong R (2009) Phenology of marine angiosperms (seagrasses): reproductive synchrony in the sea. In: Pandalai SG (ed) Functional approach to sexual plant reproduction. Research Signpost, Trivandrum, p 17-46

Verduin JJ, Backhaus JO (2000) Dynamics of plant-flow interactions for the seagrass Amphibolis antarctica: field observations and model simulations. Estuar Coast Shelf Sci 50: $185-204$

Vermaat JE, Rollon RN, Lacap CDA, Billot C and others (2004) Meadow fragmentation and reproductive output of the SE Asian seagrass Enhalus acoroides. J Sea Res 52:321-328

Walker DI, Olesen B, Phillips RC (2001) Reproduction and phenology. In: Short FT, Coles R (eds) Global seagrass research methods. Elsevier, Amsterdam, p 313-324

Waycott M, Procaccini G, Les DH, Reusch TBH (2006) Seagrass evolution, ecology and conservation: a genetic perspective. In: Larkum AWD, Orth RJ, Duarte CM (eds) Seagrasses: biology, ecology and conservation. Springer, Dordrecht, p 25-50

Williams SL (1995) Surfgrass (Phyllospadix torreyi) reproduction: reproductive phenology, resource allocation, and male rarity. Ecology 76:1953-1970

Yund P (2000) How severe is sperm limitation in natural populations of marine free-spawners? Trends Ecol Evol 15:10-13

Submitted: June 14, 2010; Accepted: October 8, 2010

Proofs received from author(s): November 24, 2010 